\title{
A Subak Analogy Model in Computer Network Subject for Vocational Student
}

\author{
Ketut Agustini ${ }^{1}$, Gede Saindra ${ }^{2}$, Nyoman Sugihartini ${ }^{3}$, Gede Indrawan ${ }^{4}$ \\ Information Engineering Education Department ${ }^{1,2}, 3$ \\ Electrical Engineering Education Department ${ }^{4}$ \\ Universitas Pendidikan Ganesha \\ Singaraja, Indonesia \\ ketutagustini@undiksha.ac.id
}

\begin{abstract}
In a computer network concept, there are abstract and concrete materials. The abstract concept might lead students to misconceptions. This can be avoided by the students' prior knowledge gained from everyday activities in accordance to the culture and environment. In bridging the abstract concepts into the concrete one, a metacognitive strategy is needed to make the received information become easier to remember and understand. The strategy is done by applying a learning model called analogy. An analogy model can be used as a tool to explain the concept that must be understood by the student. In order to be effective in its implementation, the chosen analogy should already be familiar to the students. Subak is a Balinese organization of irrigation system and is one example of local wisdom known widely in the world. Subak system with its unique resources management is similar to the concept of computer network system. Thus, this study deal with it covering students' need, their characteristic and instructional analysis. Result shows that the computer network subject can use the analogy of Subak concept.
\end{abstract}

Keywords—subak, model, computer, network

\section{INTRODUCTION}

The computer network subject, as one of the courses in the computer area, expects competencies where students are able to analyze and provide solutions in case of problems on a computer network according to the concepts that have been learned. It means that the mastery of the concepts is theoretically very important for the practical implementation [1].

On the theoretical concepts of computer networks, there are abstract and concrete materials. These abstract concepts often lead to misconceptions to the students that prevent them from implementing it practically. One of the offered solutions to the problem is by teaching with an analogy model. Such model is an explanation model of a concept or topic by the way of an analogy with an event that is easily understood by the students. To use analogy model effectively, it is necessary to refer to the concept of computer networks that has been taught and understood by students.

The concept of the referral is needed to explain the target concept, namely the concept of a computer network of new teaching materials. Overall comparisons between these two concepts can expand the mindset of both teachers and students. Moreover, the difference can prevent misconceptions by maintaining correct preconceptions or change the concept of students' thinking maps according to which the theory should work within specific teaching materials [2].

An important aspect of teaching the concept clearly defines the concept and gives selected examples carefully. Learning concept can be associated with daily life or culture that is known to facilitate the students to understand the concepts being taught. By studying and analyzing thoroughly the aspect of Indonesian culture, we may find many concepts of local wisdom that have been practiced in a daily life of Indonesian people that can be beneficial for Information Technology study $[3,4]$. Besides, in the philosophical values of life that are embraced by the people, it will affect the course of the educational process. There is a number of potential local wisdom that is relevant to the theory of modern education and learning, such as (i) the conception of learning levels, (ii) the conception of learning discipline, (iii) the conception of the learner (for teacher), (iv) the conception of how to teach, and (v) the conception of learning [5].

Teaching with Analogies (TWA) model creates a map comparison (mapping) between the reference concepts and the target concept. If there are many similarities between these two concepts, then a thinking analogy can be built. The concept of analogy needs to be selected carefully. If the student gets less familiar with the analog concepts, the students will not be able to understand the contents of the learning, as well as an easy target concept to visualize the analogy learning is no longer needed [6].

According to Kwen and Aun, there are a few advantages using the analogy in teaching, such as (i) the analogy as a tool to teach conceptual change, (ii) the analogy provides visualization and understanding the abstract concepts that refer to examples in real life, (iii) the analogy may spark students' interest, therefore having a motivational effect, and (iv) the analogy requires teachers to consider the students' preconceptions of the material to be taught and can eliminate or reduce misconceptions on the material being taught [7].

Then Glynn states that there are 6 steps for teachers to attract or obtain an analogy [6], i.e.:

- Introducing the target concept. Target concept is a concept that is not common or is not well known and will be taught to students.

- Reviewing completed or reviewed the analogy concept. This concept is general or well known and usually has the first material taught to students. 
- Identifying or looking for features or attributes relevant between the target and analogies. Collecting all good features or attributes of the target concept and the concept of analogy to be identified.

- Mapping the similarity between the analogy and target concepts. The process of benchmarking all the features/attributes is obtained by the so-called mapping. If there are a lot of similar features/attributes, an analogy can be drawn or taken. The more similar the features/attributes, the better the analogy.

- Identifying or looking for exceptional circumstances in which the analogy does not work. Features/attributes that are not similar is the exception to the analogy.

- Taking conclusions about the target concept.

The use of an analogy model is an activity that triggers a person's cognitive in learning. With an analogy concept, students can easily understand a difficult target concept to be visualized. This is a metacognitive strategy in learning where students make a concept easier to understand.

Metacognition refers to a person's understanding of knowledge so that a deep understanding of knowledge will reflect the effective use or a clear description of the knowledge itself. This indicates that the knowledgecognition is a person's consciousness about what is actually known. Meanwhile, a regulation-cognition is how one effectively regulates the cognition activity. Therefore, knowledge-cognition includes declarative, procedural, and conditional knowledge, while, regulatory-cognition includes planning, prediction, monitoring, testing, revision, checking and evaluation. The purposes of this current study are to conduct content analysis of Subak concept analogized to the concept of computer networks, making it easier for students to understand a concept.

\section{METHOD}

This paper is part of the recent study namely an instructional analysis stage that analyzes the concept of Subak analogized to the concept of computer networks. Previous studies have been done on a need, learner's characteristics and context analysis. All of the taken steps followed Dick and Carey's development model.

To analogize a concept, it is necessary to make a comparison map between the reference concept and the target concept in implementing TWA model. The concept is already known as analogy while the target of the model is caleed as a target. Then between the analogs and the target, there are features that are said to be attributed. If the analogs and the target have a common feature, the analogy would be visualized. In the concept of Subak analogy with the computer network can be seen in Figure 1. The concept of Subak as an analog concept has been widely known by the public, especially Bali as one of the local wisdom that has been recognized by UNESCO as world cultural heritage. Subak as an organization has the same concept with computer organization that manages limited resources to be optimized and effective in its utilization.

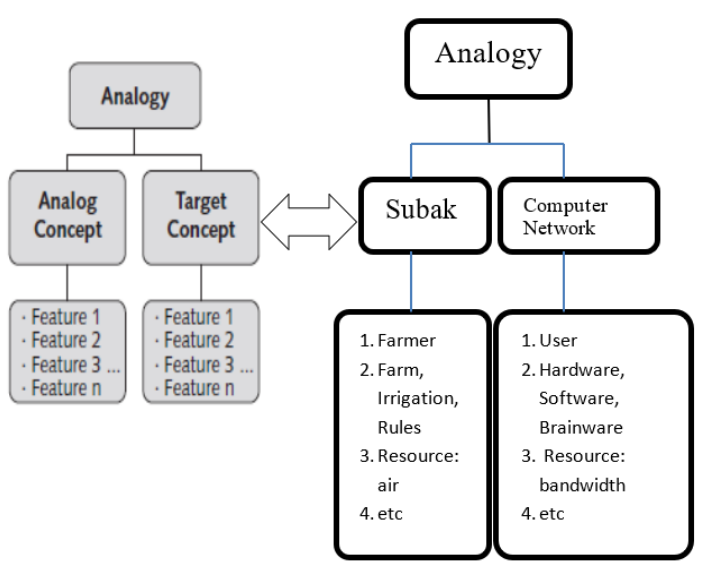

Fig. 1. Conceptual representation of the analogy model

\section{RESUlt AND Discussion}

The results of in-depth descriptive analysis of the subak analogy model in computer networking concept were adapted to the syllabus used in computer network course.

An analog concept of subak irrigation system, also called a water control system, manages a network of irrigation from the same water source, so that the outline of subak is also supported by three main components namely (i) hardware, namely infrastructure and irrigation infrastructure such as tembuku, and building reservoir, (ii) software, i.e. processes undertaken since planting the seed to harvest along with a series of religious ceremonies, such a period of cropping patterns, nugtug toya ceremony and (iii) users, all concerned members of subak.

Target concept in computer networks is a computer system which is supported by three main components, namely, (i) the hardware, the computer itself, (ii) the software, application programs such as windows applications, antivirus application, (iii) the brainware, that all parties are responsible for system development and users.

The three main components of input devices, process tools, and tools contained in the output of the system concept Subak. Subak as a unit (physical unit) has subsystem artifacts (relics of historic objects) that also serve as input devices, the process tool, and the output tool as follows: (i) roads in Subak area, (ii) Subak irrigation canals, (iii) the exact boundaries of the relevant Subak, (iv) tunnel in Subak concerned, (v) relationships (Tembuku) in Subak concerned, (vi) doors getter or tapping (Tembuku pengalapan) on each block or complex of individual paddy farmers, (vii) drainage canals or drains in each block/complex of individual paddy farmers.

The physical aspect means that one who ensures the flow of water irrigation according to the needs of each subak member. It is analogous to the target concept of a computer network which has three parts of computer hardware namely the input device, process, and instrument output.

Subak concept contained in analogous interrupting mechanism which is applied in the process of water distribution. During the period from planting to harvest, process of water distribution will be carried out in accordance with the initial agreement that has taken place between all subak members. But in its implementation, a 
member of subak could have been raising concerns over the distribution of water they receive. The mechanism occurs in the concept of a target computer network, the occurrence of an event marked by an interruption, which probably comes from the hardware or software parts.

The primary medium storage in subak system can be artificial or natural lake dam. Water irrigation is the main resource managed by subak system and stored in dams or lakes, henceforth circulated irrigation could channel to the rice fields. While coping with the concept of a target computer network, computer programs must be in main memory known as a random access memory. The main memory is the only large-sized storage area that can let processors access directly.

The subak system does not have a secondary storage media because water irrigation continues to flow through the irrigation network. But there are times when a large water control system makes a water container (reservoir) for the areas of rice fields which are located far away from the main water storage. The reservoir that will accommodate seepage water is wasted when the paddy fields located more above do not use the water irrigation. On the concept of a target computer network, the computer system has a secondary storage in addition to the main memory. The basic necessity of that must be fulfilled by secondary storage that is able to save a number of large amounts of data permanently.

\section{A. The distributed system concept}

In the concept of subak system, if a water control system has several reservoirs, the storage hierarchy structure will depend on the location of each reservoir, according to the water flow diagram from the highest to lowest location closest to the paddy fields. Same with the water control system concept, the concept of a target computer network has the potential variations in the storage system in which a computer system can be organized in a hierarchy according to the speed and cost.

Coherence and consistency are also a very important thing in the Subak system. Discharge of water flowing on the network Subak irrigation system should also be coherent and consistent with the needs that have been agreed. The water discharge must be properly counted in the distribution channels and enter the channel outputs from each channel irrigation and paddy fields so that is not to provoke conflict between members of Subak. One should also note Subak irrigation network conditions, which may lead to partial loss of irrigation water discharge when water flows through the channels that are not perfect (there are leaks). This is similar to the concept of a target computer network, there are coherence and consistency in the increment process that are done in internal registers.

A distributed system occurs in a region of Subak Gede, efforts to maintain the coherence and consistency of flowing water discharge becomes more complex. A rice field area could receive water input from several sources originating from different regions of Subak. The process of negotiation and compromise will be a distribution of water that should be made between sedahan of each Subak region. Besides the need to calculate the flow of water received in Subak irrigation belt, it should also be considered discharge overflow of water received from other water control systems that happen to be close to the borders of each Subak. The same thing also happened to the concept of a target computer network, in a distributed environment, the situation becomes more complicated. In a multiple distributed environment copies of the same file can be stored on different computers. Because multiple copies of a file can be accessed and updated concurrently, we must ensure that when an updated copy, the copy of the files also should be updated as soon as possible.

In analogy to the concept of Subak, recognize and distinguish the water distribution system (distributed), i.e. network system. Two or more water control systems can combine to form a larger Subak organizations in which usually each Subak uses the main source of water comes from a large river, as in Figure 2.

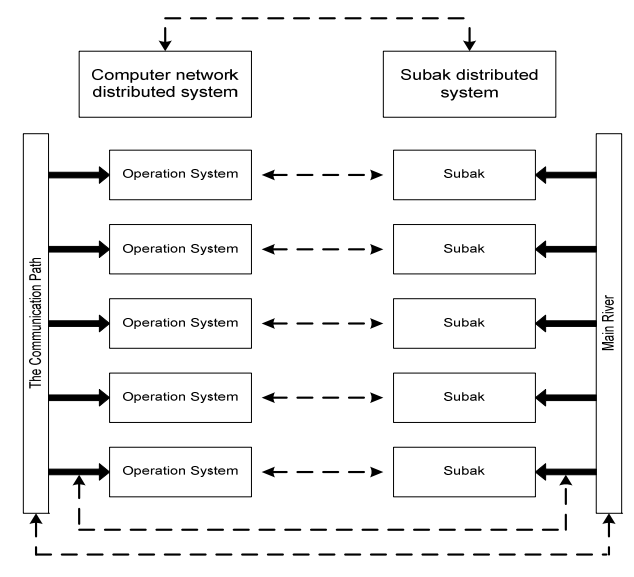

Fig. 2. Subak in the distributed system concept [6]

However, each Subak will have each draft of water. The water distributed in between some of the Subak is found lots of Subak local knowledge as a quite complex operating system. As a number of ceremonies was held by the order of planting, time sequence, or to anticipate any extraordinary event such as pests and so on. Meanwhile, as an irrigation network, the Subak system more emphasizes on the channel, building, and equipment/ hardware such as Tembuku, empelan, and tektek, which ares integrated and necessary for the regulation of water irrigation from the provision, retrieval, and use. More details will be explained in the computer networking devices. In a computer network, the user must explicitly log into a machine, explicitly express their duties remotely, explicitly move files and handle themselves in general search network management. In a distributed system, nothing needs to be done explicitly, everything is done automatically by the system without the user's knowledge. Thus a distributed system is a software system that is made on the part of a computer network. The software that determines the level of integrity and transparency of the network in question. Because of the differences in the network with a more distributed system lies on its software (especially the operating system), not on its hardware

In the irrigation network, Subak system is a reflection of the concept of Tri Hita Karana (THK) which teaches that each person is always seeking a balance between servitude to God (Parahyangan) with their service to fellow human beings (Pawongan), as well as the love of caring for the natural environment (Palemahan) in order remain sustainable 
as Figure 3, has provided many benefits for agriculture in Bali (Bali Ajeg) for hundreds of centuries ago.

The form of Tri Hita Karana in Subak irrigation system is a system that is socio-technical, whose technology has been fused with the socio-cultural community. The benefits of Subak as an embodiment of the THK concept in network operations Subak irrigation system include;

- Benefits seen from subsystem culture that is reflected by the mindset of water irrigation management based on the harmony and togetherness. Example: Organizing Magpag Toya ceremony together with Subak members, making sacred temple (Bedugul temple) in land remaining on the location of the shared building.

- Benefits were seen from the social subsystem that is reflected by the existence of Subak organizations that are tailored to the interests of farmers so that the desired goals can be achieved. Also, conflicts in the Subak can be avoided in order to create harmony. Example: Making awig awig (regulation) to be adhered to by all the members and officials of Subak, the meetings held to reach a mutual agreement.

- Benefits were seen from subsystem artifact that is reflected by the availability of irrigation network in accordance with the needs of Subak, the distribution is equitable and borrowing process water. Thus, conflicts can be prevented. Example: distribution of water use tektek system, drainage system and separated suppletion in a complex rice field known as the "one inlet and one outlet system", and the provision of additional water in case the water supply is lacking in farmers' fields.

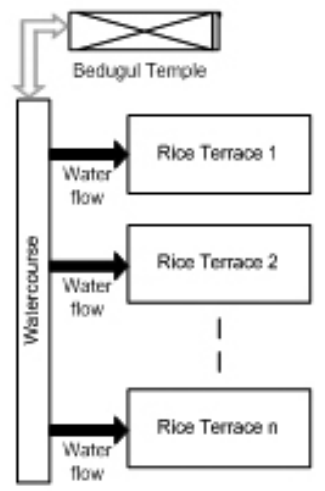

Fig. 3. Subak networking in Tri Hita Karana (THK) concept

Figure 3 is a visualization of subak system in THK concept that is analogous to Time Sharing System in computer networks. The Subak irrigation system, as well as farmers' organization in the field of irrigation, has a goal to provide emotional and physical well-being for its members through the efforts of food production, especially rice. It is necessary for various activities or important tasks that include, (i) water management, which is the main resource in the set of sharing and draining the water in order to be best utilized by farmers who are members of Subak in fields respectively, (ii) the management of the physical infrastructure of irrigation, especially the repair and maintenance of irrigation networks, (iii) the mobilization of manpower and fund-raising, (iv) management of conflicts that arise in particular related to the use of water and with a variety of activities in subak, (v) the implementation of religious rituals that are closely related to rice cultivation, and (vi) subak meetings for decision making.

The related context of the division of water resources, telabah pengalapan or a quarter will distribute water to every individual farmer who have cultivated paddy fields, while bedugul temple is sacred buildings used by members of Subak as a venue for collective ritual.

On the introduction, two types of transmission technology include network broadcast and point-to-point, of which the analogy with the concept of Subak is viewed from the transmission technology using a network broadcast. The scope of distribution of rice fields that enter into the territory of a particular Subak is largely determined by factors of the geographical location of the paddy fields. Subak is indigenous people in Bali who are socio-agrarian, economical and dynamic in the field of regulating the use of irrigation for paddy. Subak members are farmers, including the tenants.

A network topology in Subak system is strongly influenced by the geographical location of Subak itself against the broad range of distribution of water resources to farmer's paddy fields. If the geographic location of paddy farmers is in parallel with the main water source/river/dam, then it will shape a topology bus. Meanwhile, if the main source of water/river/dam is geographically centralized, the topology is the main shape. Thus, in the system of Subak, all depend on the geographical location of the main water source/river/dam (uncertain topology as WAN).

WAN concept is found in a big Subak (Subak Gede) network. Subak Gede consists of several dams and water control system using several irrigation infrastructures. In big water control system, communication established between the heads of Subak became parts of Subak Gede. The process of water distribution and utilization of irrigation channels will become increasingly complex. Conflicts which may arise will also be more complex as it may involve Subak members coming from different Subak regions.

\section{B. Subak concept analogy in TCP/IP and OSI}

In the layers of the content on the TCP / IP to view the function of each layer in the TCP / IP, Subak system also has a layer that functions analogous to each layer above. As an irrigation system, water irrigation or control system has a network of irrigation facilities such as buildings to manage and distribute water irrigation from the source of water to the rice fields of individual farmers. The irrigation facilities consist of irrigation channels along with irrigation and buildings awig awig (rules/protocol for the management of Subak) as well as meeting the Subak (interaction and communication between citizens Subak) which is an integrated system of irrigation networks (see Figure 4). 


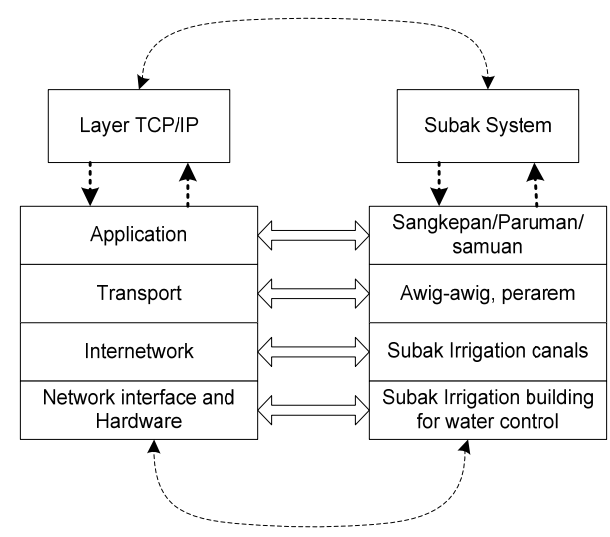

Fig. 4. Subak concept analogy in TCP/IP Layer

Sangkepan/Paruman/Samuan is a container consultation and communication between the board and Subak citizens about important issues concerning the management of Subak that needs to look for a solution. Awig awig/perarem is a rule (like a network protocol) that makes Subak residents control access by members of Subak system resources such as regulating the function of delivery of water resources upstream to downstream. Subak irrigation channels are line(s) the flow of water from an upstream source to the rice fields of farmers (downstream / end). Subak irrigation channels include aungan, tunnels (if closed), big telabah, big Pemaron telabah, telabah Pemaron Cenik, telabah pengalapan, talikunda and telabah pengutangan. Buildings as an irrigation water control system is physical facility (hardware) owned network for setting Subak irrigation water, ranging from the provision, retrieval, and use. The physical building form, empelan (dam), Tembuku aya, Tembuku Pemaron gede, Tembuku Pemaron Cenik, Tembuku pengalapan and other additional buildings (petaku/taku, pekiyuh, abangan).

In connection with the OSI model compared with TCP / IP, the analog with the concept of Subak is better known as the setting of irrigation systems, in which water control system is also a complex organization. Therefore, we need a structure protocol network model that can simplify tasks such as high complexity into smaller layers. As already presented in the discussion of TCP / IP, Subak system recognizes the existence of four layers as in figure 5, which have the function of each and a unity
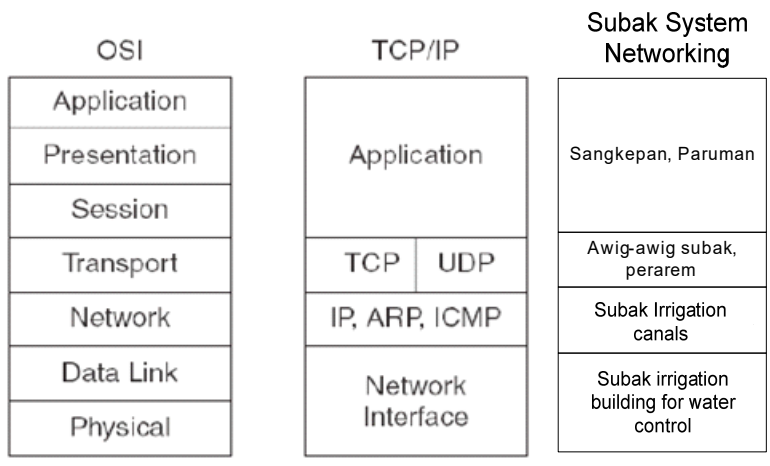

Fig. 5. OSI model, TCP/IP, Subak System Network
As an organization, Subak has members (manners), administrators (prajuru) as well as the articles of association (awig awig) and supplementary budgets (perarem). Subak members do not directly access the Subak resources. Subak system or set of rules must provide a mechanism to access the resource on behalf of members of Subak. In this case, communication between members of Subak through Sangkepan/Paruman (formal communication) is necessary to access the resource usage (Application Layer).

The main thing that is discussed in Sangkepan / Paruman is rice planting activity where all these activities require the collective resources such as water, canal/dam/irrigation channel, pura Subak (irrigation) and others. Rice planting activities (presentation and session layer) cover (i) scheduling and cropping patterns of all members of Subak, (ii) controlling the process of planting and harvesting process of a whole area of rice fields, (iii) providing a mechanism to synchronize the planting and harvesting schedules, (iv) providing a mechanism for communication between members of Subak who have agricultural activities that conflict with the activities of other members of Subak.

Furthermore, under the agreement / sangkepan result/awig awig (transport layer) of water resources/data package will flow to the addressee through irrigation channels Subak such as big telabah, telabah Pemaron, telabah pengalapan, and talikunda to the rice fields of farmers (the network layer). The basic water regulation of Subak system is tektek or cecah (width size water splitters made of wood that has divided grooves). The water distribution tool called Tembuku regards to a divider measure (the data link and physical layer). Sesukat rice field (plot) obtained one tektek division, when the rice seedlings one tenah where tenah is the size of rice weighing less than $25 \mathrm{Kg}$. Water distribution is done on the basis of the combination of the area size and the collective agreements between users, which are implemented by the division structure using water standing.

Relating to the computer network, as well as the system of Subak, as a physical unit that implicitly reflect technological systems, water control system has a network of irrigation or irrigation facilities such as buildings needed (hardware) for the regulation of irrigation water from the water source (source/server) to the rice plots of individual farmer (client). The irrigation facilities consist of irrigation channels like the transmission medium in a computer network and its building is an integral irrigation network.

Subak irrigation is a directional transmission medium comprising the main channel (primary) of a water control system. If the tunnel is closed then called aungan otherwise if it is open, then called big telabah / telabah aya. A big Telabah Pemaron is a secondary bearer channel that irrigates one specific part of the Subak rice-fields. A smaller Telabah Pemaron (telabah Cenik) is a tertiary bearer channel that irrigates parts of the region that are smaller than parts of Subak irrigated by big telabah Pemaron. Telabah pengalapan / penyahcah is a quarter channel that irrigates one or more blocks of the fields belonging to individual farmers in which one or more elbows / tuluk / cutak paddy fields belonging to individual farmers (average of about 35 acres) can consist of several fields. When used by about 10 farmers individually, it refers to telabah penasan, whereas if it is used to irrigate the rice fields around the tuluk of 5 individual ( 5 members of Subak) is known as five telabah. Buildings for the telabah 
penasan and five consecutive were called Tembuku penasan and Tembuku Lima. The process of building work for Tembuku like a switch in computer networks that share the bandwidth equally to each port. Talikunda / samakunda are channels that distribute water equitably for each elbow fields. Telabah pengutangan is the channel to dispose of excess water (sewer / drainage).

The building of Subak irrigation (Hardware) consisting of Empelan /dam is water catchment in the river along with the open entry which becomes the main/principal building such as Tembuku, a building for the Subak system built with the proportional concept namely from the upstream until the the rice fields of farmers (Tembuku pengalapan). Building pura (Bedugul) is a sacred building which is used as a venue for collective ritual at the Subak. Other complementary buildings like petaku/taku (building waterfalls), pekiyuh / pepiyuh (the building next to the spillway on irrigation channels) serve as a drain and a relatively safe place to drain the remaining water.

For students in Bali, Subak concept is not a new thing. Mastery and understanding of the concept of Subak is a contextual experience that can be applied to the student in the learning process. The concept of learning integrates the student experience into a learning situation, which is in line with the constructivist views. As disclosed, there are two aspects of the social context influenced by the progress and level of learning namely: first, the acquisition of a student of the culture such as language, the use of mathematics and logical system, which develop throughout life [8]. Second, there is a wider social interaction between members of society.

In their view, Pritchard and Woollard call the cultural aspects as the acquisition of learning outcomes. In this context, the culture of Bali in form of Subak, an initial experience and knowledge, can be synergized by the faculty and students to understand the concept of computer networks. This is also supported by the theories expressed Ausubel which highlights the importance of prior knowledge of the students and the importance of providing students the relationship between prior knowledge and new knowledge to be taught.

The synergy between a contextual understandings of learning experiences will complement each other. Build learning situations that integrate and connect the concrete experiences of students about the context that has been understood by the teaching situation can build motivation to learn and connect the "why" of a concrete reality in the teaching process provides important motivation which is necessary to learn. Clearly, collaborative students' contextual learning experience can be done through analogy, which is believed to be capable to provide learning motivation and enthusiasm. This course will assist the process of achieving the desired learning objectives.

\section{CONCLUSION}

Based on the results, it could concluded that subak analogy modul can used as computer network analogy to help students to understand and implement computer network project.

\section{REFERENCES}

[1] Agustini, K. "Pengembangan Media Pembelajaran Berbasis Hypertext Pada Komunikasi Data Dan Jaringan Komputer Berorientasi Konsep Subak.” Jurnal Teknologi Pendidikan, vol. 17, no. No.1 April. ISSN 1411-2744, 2015, pp. 63-67.J.

[2] Kesiman, Made Windu Antara, and Ketut Agustini. "The Implementation of Hypertext-Based Learning Media for a Local Cultural Based Learning." Journal of Information Technology Education: Innovations in Practice, vol. 11, 2012, pp. 377-85.

[3] Agustini, Ketut. The Handbook Model of Computer Networks Based On The Local Wisdom Value of Subak Concept The Handbook Model of Computer Networks Based On The Local Wisdom Value of Subak Concept. no. November 2014, 2015.K. Elissa, "Title of paper if known," unpublished.

[4] I Wayan Suastra. "Model Pembelajaran Fisika Untuk Mengembangkan Kreativitas Berpikir Dan Karakter Bangsa Berbasis Kearifan Lokal Bali.” Konaspi VII Universitas Negeri Yogyakarta, 2012Universitas Negeri Yogyakarta, 2012, 2012, pp. 544-60.

[5] Wayan Subagia dan I Gusti Lanang Wiratma. "Potensi-Potensi Kearifan Lokal Masyarakat Bali Dalam Bidang Pendidikan.” Jurnal Pendidikan Dan Pengajaran, vol. 3 TH XXXIX, no. 3, 2006, pp. 552 65.

[6] Glynn, Shawn M. "Making Science Concepts Meaningful to Students: Teaching with Analogies." Four Decades of Research in Science Education: From Curriculum Development to Quality Improvement, 2008, pp. 113-25.

[7] Fathurohman, Apit. “Analogi Dalam Pengajaran Fisika.” Jurnal Inovasi Dan Pembelajaran Fisika ISSN : 2355-7109, vol. 1, no. 1, 2014, pp. 74-77.

[8] Pritchard, A. Woollard, J. Psychology for The Classroom: Constructivism and Social Learning. 2010. 